\title{
Source-sink relationships for carbon and nitrogen during early growth of Juglans regia L. seedlings: analysis at two elevated $\mathrm{CO}_{2}$ concentrations
}

\author{
Pascale Maillard $^{\mathrm{a}}{ }^{*}$ Éliane Deléens ${ }^{\mathrm{b}}$, Frédéric Castell $^{\mathrm{a}}$, François-Alain Daudet $^{\mathrm{a}}$ \\ ${ }^{a}$ Laboratoire de physiologie intégrée de l'arbre fruitier, Inra, Domaine de Crouelle, 63039 Clermont-Ferrand cedex 02, France \\ ${ }^{b}$ Laboratoire de structure et de métabolisme des plantes, CNRS, ERS 569, Université Paris XI, 91405 Orsay cedex, France
}

(Received 5 February 1998; accepted 8 June 1998)

\begin{abstract}
Assimilation and allocation of carbon (C) and nitrogen (N) were studied in seedlings ( $J$ uglans regia $\mathrm{L}$.) grown for 55 days under controlled conditions $\left(22^{\circ} \mathrm{C}, 12 \mathrm{~h}, 90 \%\right.$ relative humidity $[\mathrm{RH} \mid)$ using two $\mathrm{CO}_{2}$ concentrations $\left(550\right.$ and $\left.800 \mu \mathrm{L} \mathrm{L}-1 \mathrm{CO}_{2}\right)$. C and $\mathrm{N}$ decrease in seeds was unaltered by $\mathrm{CO}_{2}$. At the end of seed contribution (day 35), $\mathrm{C}$ and $\mathrm{N}$ accumulation in seedlings was favoured under $800 \mu \mathrm{L} \mathrm{L}^{-1}\left[\mathrm{CO}_{2}\right]$, resulting in an increase of about $+50 \%$ for $\mathrm{C}$ and $+35 \%$ for $\mathrm{N}$. Growth enhancement was larger in roots than in shoot, resulting in a higher root:shoot ratio $(\mathrm{R}: \mathrm{S}=0.62)$ with respect to $550 \mu \mathrm{L} \mathrm{L}^{-1} \mathrm{CO},(\mathrm{R}: \mathrm{S}=0.40)$ at day 55 . These results were due, in order, to: 1) a shoot respiration temporarily depressed by $\left[\mathrm{CO}_{2}\right], 2$ ) a reduction by $46 \%$ of the root + soil respiration, 3) a stimulation by $14 \%$ of the $C$ assimilation and 4 ) an increased uptake and assimilation of $\mathrm{N}$ coming from the rooting medium. An increased use of $\mathrm{N}$ originated from the seed was observed in leaves and lateral roots, suggesting optimisation of distribution of stored $\mathrm{N}$ pools by seedlings. These changes finally gave rise to an increased $\mathrm{C}: \mathrm{N}$ ratio for taproot $(+27 \%)$, roots $(+20 \%)$, stem $(+28 \%)$, and leaves $(+12 \%)$, suggesting a $\mathrm{N}$ dilution in the tissues. (C) Inra/Elsevier, Paris.)
\end{abstract}

Juglans regia / $\mathrm{CO}_{2} / \mathrm{C}$ balance / ${ }^{15} \mathrm{~N} /$ shoot / root

Résumé - Relations source-puits pour le carbone et l'azote durant les premiers stades de croissance de semis de Juglans regia L. : analyse à deux concentrations en $\mathrm{CO}_{2}$ atmosphérique élevées. L'assimilation et la répartition du carbone (C) et de l'azote ( $\mathrm{N}$ ) ont été étudiées chez des semis de Juglans regia L. cultivés 55 j en conditions contrôlées $\left(22^{\circ} \mathrm{C}, 12 \mathrm{~h}, 90 \% \mathrm{H}\right.$. R.) à deux teneurs en $\mathrm{CO}$, atmosphérique $\left(550\right.$ et $800 \mu \mathrm{L} \mathrm{L}^{-1} \mathrm{CO}_{2}$ ). La diminution en $\mathrm{C}$ et $\mathrm{N}$ des graines n'est pas modifiée par la teneur en $\mathrm{CO}_{2}$. L'accumulation de $\mathrm{C}$ et $\mathrm{N}$ dans les plants est augmentée de $50 \%$ et $35 \%$ respectivement à $800 \mu \mathrm{L} \mathrm{L}^{-1} \mathrm{CO}_{2}$, dès l'arrêt de la contribution de la graine (j 35). Sous la plus forte teneur en $\mathrm{CO}_{2}$ le gain de croissance observé est plus important pour le système souterrain qu'aérien aboutissant à un rapport tige-racine augmenté $(0,62)$ à $800 \mu \mathrm{L} \mathrm{L}^{-1} \mathrm{CO}_{2}$ comparé à $550 \mu \mathrm{L} \mathrm{L}^{-1} \mathrm{CO}_{2}(0,40)$. Ces résultats sont dus à $(1)$ une respiration temporairement déprimée par le $\mathrm{CO}_{2},(2)$ une diminution par $46 \%$ de la respiration sol + racines, (3) une stimulation par $14 \%$ de l'assimilation du C, et (4) une augmentation de l'absorption et de l'assimilation de l'azote du sol. Une augmentation de l'utilisation de l'azote originaire de la graine est observée dans les feuilles et les racines latérales suggérant une optimisation de l'utilisation et de la répartition de l'azote stocké par les plants. Ces changements aboutissent à une augmentation du rapport $\mathrm{C} / \mathrm{N}$ pour le pivot $(+27 \%)$, les racines $(+20 \%)$, la tige $(+28 \%)$, et les feuilles $(+12 \%)$, suggérant une dilution de l'azote dans les tissus. (C) Inra/Elsevier, Paris.)

Juglans regia / $\mathrm{CO}_{2} / \mathrm{C}$ balance $/{ }^{15} \mathrm{~N} /$ tige / racine

\footnotetext{
* Correspondence and reprints

Present address: unité d'écophysiologie forestière, Inra Nancy, 54280 Champenoux, France
} 


\section{INTRODUCTION}

Growth and survival of young plants, particularly during the transition to an autotrophic existence, depend on both efficient use of seed reserves and new photosynthates $[15,25,33]$. In this context, environmental conditions and changes in resource availability will notably influence trophic relationships between the seed and its emerging seedling, and the chances of a successful establishment $[8,15,29]$. For tropical and temperate forest ecosystems it was shown that steep $\mathrm{CO}_{2}$ gradients exist between the forest floor and the top of the canopy $[3,4]$. Elevated $\mathrm{CO}_{2}$ concentration ( 400 to $550 \mu \mathrm{L} \mathrm{L}^{-1}$ ) near the soil surface particularly, due to intensive soil respiration, is very frequent in forests $[3,4]$, suggesting that in natural regeneration systems emerging seedlings frequently grow under elevated $\mathrm{CO}_{2}$ concentrations. Nevertheless, little work has focused on the influence of elevated $\mathrm{CO}_{2}$ concentration on seed germination and emergence [42], even though, in light of experiments on tobacco [28], principal changes of metabolism and growth under elevated $\mathrm{CO}_{2}$ would occur early after germination. Moreover, understanding how heterotrophic seedlings respond to elevated $\mathrm{CO}_{2}$ can be of importance regarding biomass and plant production in field or greenhouse situations, as shown by Kimball $[21,22]$.

In order to gain a better understanding of the fate of carbohydrates and nitrogen $(\mathrm{N})$ nutrients in young heterotrophic walnut trees (Juglans regia L.), carbon (C) and $\mathrm{N}$ partitioning between organs and physiological functions (growth, respiration and reserve storage) were previously investigated under $550 \mu \mathrm{L} \mathrm{L}^{-1} \mathrm{CO}_{2}[25,26]$. After this initial investigation, interactions between sink organs and the two source organs (seed, leaves) to the translocation and distribution of assimilates in the seedling remained unclear even though the use of a deterministic and dynamic model of carbon allocation [17] indicated that an intensive competition for carbohydrates dominates the relations among organs during transition to autotrophy.

Experimental changes of source-sink balance in plants by organ removing or light treatment can help considerably in changing the distribution pattern of photoassimilates compared with control plants and the study of possible mechanisms controlling source-sink relationships $[18,35]$. In the present study, we attempted to alter both photosynthetic supply and source-sink relationships for $\mathrm{C}$ and $\mathrm{N}$ of heterotrophic walnut seedlings growing under $550 \mu \mathrm{L} \mathrm{L}^{-1} \mathrm{CO}_{2}$ by increasing the $\mathrm{CO}_{2}$ concentration. In fact, manipulating the photosynthetic supply of plants by $\mathrm{CO}_{2}$ to alter source-sink relationships for $\mathrm{C}$ and $\mathrm{N}$ prevent complex morphogenetic responses generated by organ removing or environmental light changes $[1,23$,
39]. We examined the consequences of the expected gain in photoassimilated $\mathrm{C}$ on growth and on the patterns of $\mathrm{C}$ and $\mathrm{N}$ partitioning between sources and sinks of seedlings, and specifically addressed the following set of questions. To what extent might changes in $\mathrm{C}$ assimilation alter 1) the import of maternal $\mathrm{C}$ and $\mathrm{N}$, 2) $\mathrm{N}$ uptake and assimilation, 3) partitioning of $\mathrm{C}$ and $\mathrm{N}$ between shoot and roots and 4) the time lapse prior to a complete independence of the seedling from seed reserves? The relative contributions of the two sources of organic $\mathrm{N}$ (seed reserves, plant assimilation) available during the early stages of seedling growth were investigated by using the natural differences in the abundance of the stable isotopes ${ }^{15} \mathrm{~N}$ and ${ }^{14} \mathrm{~N}$ in the nutrient solution and the seed.

\section{MATERIALS AND METHODS}

\subsection{Plant material and culture conditions}

Seeds of Juglans regia L. (c.v. Franquette) were obtained from Inra (Bordeaux, France). For each $\mathrm{CO}_{2}$ treatment, 200 seeds were soaked for $48 \mathrm{~h}$ under running water at room temperature. The seeds were planted in pots filled with vermiculite and maintained under controlled conditions for 60 days in an automatically controlled climatic chamber $\left(22 \pm 1{ }^{\circ} \mathrm{C}, 12 \mathrm{~h}, 90 \%\right.$ relative humidity $[\mathrm{RH}])$. The chamber $(1000 \mathrm{~L})$ which held 20 containers, was divided into tightly sealed compartments: the upper compartment $(750 \mathrm{~L})$ contained the canopy of the plants, and the lower one ( $250 \mathrm{~L})$ the soil containers. The two parts were separated by an opaque plastic cover with 20 holes (one for each container). Access to the inside of the chamber could be obtained through three doors sealed hermetically during measurements of $\mathrm{CO}_{2}$ exchange. Ambient $\mathrm{CO}_{2}$ concentration was maintained at $550 \mu \mathrm{L} \mathrm{L}^{-1}$ in accordance with Maillard et al. [25-27] or at $800 \mu \mathrm{L} \mathrm{L}^{-1}$ with an industrial $\mathrm{CO}_{2}$ flow $\left(5 \% \mathrm{CO}_{2}\right.$, $19.1 \% \mathrm{O}^{2}$ and $75.9 \% \mathrm{~N}^{2}$ ) controlled by an infrared gas analyzer (IRGA; ADC $225 \mathrm{MK} 3$, The analytical Development Co., Ltd., Hoddesdon, Hertfordshire, UK) and an automated regulation system as described previously by Maillard et al. [25]. Gas exchange rates, i.e. shoot, root + soil respiration, and net $\mathrm{CO}_{2}$ assimilation, were measured and calculated from the time course of $\mathrm{CO}_{2}[25]$.

Light was supplied by a bank of 12 mercury vapour discharge lamps (OSRAM HQITS $250 \mathrm{~W}$ ) which provided the plant chamber with $420 \mu \mathrm{mol} \mathrm{m} \mathrm{m}^{-2} \mathrm{~s}^{-1}$ photosynthetically active radiation (PAR) at plant level. For 2 months, the plants were watered automatically four times a day with a nutrient solution [24] which contained 2.0 $\mathrm{mM} \mathrm{KNO}_{3}, 2.1 \mathrm{mM} \mathrm{Ca}\left(\mathrm{NO}_{3}\right)_{2}$ and $0.6 \mathrm{mM}\left(\mathrm{NH}_{4}\right)_{2} \mathrm{SO}_{4}$. 


\section{2. $\mathrm{C}$ and $\mathrm{N}$ analyses}

Five to ten seedlings were sampled twice a week at the end of the photoperiod for $\mathrm{C}, \mathrm{N}$ and ${ }^{15} \mathrm{~N} /{ }^{14} \mathrm{~N}$ isotope ratio analyses. Due to their small weight, the different organs (leaves, stem, taproot, lateral roots and kernel) of the harvested seedlings were pooled respectively, frozen quickly in liquid $\mathrm{N}_{2}$, freeze-dried, weighed and ground to a fine homogeneous powder with a laboratory mill. Samples were stored at $-20^{\circ} \mathrm{C}$ before analysis of biochemical content and isotope composition.

Total $\mathrm{C}$ and $\mathrm{N}$ contents and isotope ratio ${ }^{15} \mathrm{~N} /{ }^{14} \mathrm{~N}$ in plant material were measured using the corresponding gases derived from the combustion of aliquots of plant tissues, and analysed in an elemental analyser (CNRS, Service Central d'Analyses, Lyon, France) coupled with a mass spectrometer (Delta S, Finnigan, USA). All samples were analysed at least twice. Isotopic composition was expressed in $\delta$ units versus $\mathrm{N}_{2}$ of ambient air as a standard:

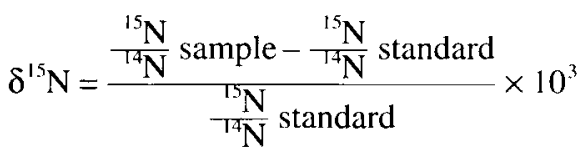

The error (standard deviation) between repeated analyses of the same plant sample was between 0.03 and $0.14 \%$. Nutrient solution used exhibited values of $\delta^{15} \mathrm{~N}$ at $-3 \%$ and kernel values of $\delta^{15} \mathrm{~N}$ at 5 .

The proportion of $\mathrm{N}$ assimilated from the nutrient solution in total $\mathrm{N}$ of the plant sample was calculated as follows [11]:

$$
\mathrm{N}_{\mathrm{p}}=\frac{\delta^{15} \mathrm{~N} \text { organ }-\delta^{15} \mathrm{~N} \text { kernel }}{\delta^{15} \mathrm{~N} \text { nutrient solution }-\delta^{15} \mathrm{~N} \text { kernel }} \times 10^{2}
$$

with $100-\mathrm{Np}=\mathrm{Nk}$ corresponding to the proportion of $\mathrm{N}$ coming from seed reserves.

\section{RESULTS}

\subsection{Time course of cumulated $\mathrm{C}$ exchanges in whole seedlings}

Figure 1 shows cumulated $\mathrm{CO}_{2}$ exchanges from day 21 to day 55 (end of experiment). Day 21 corresponded to the beginning of a measurable net $\mathrm{CO}_{2}$ assimilation, i.e. 6 days after emergence of the first two leaves. Photosynthetic $\mathrm{C}$ accumulated exponentially until day 55 (figure 1A). Differences in the photosynthetic $\mathrm{C}$ accumu-

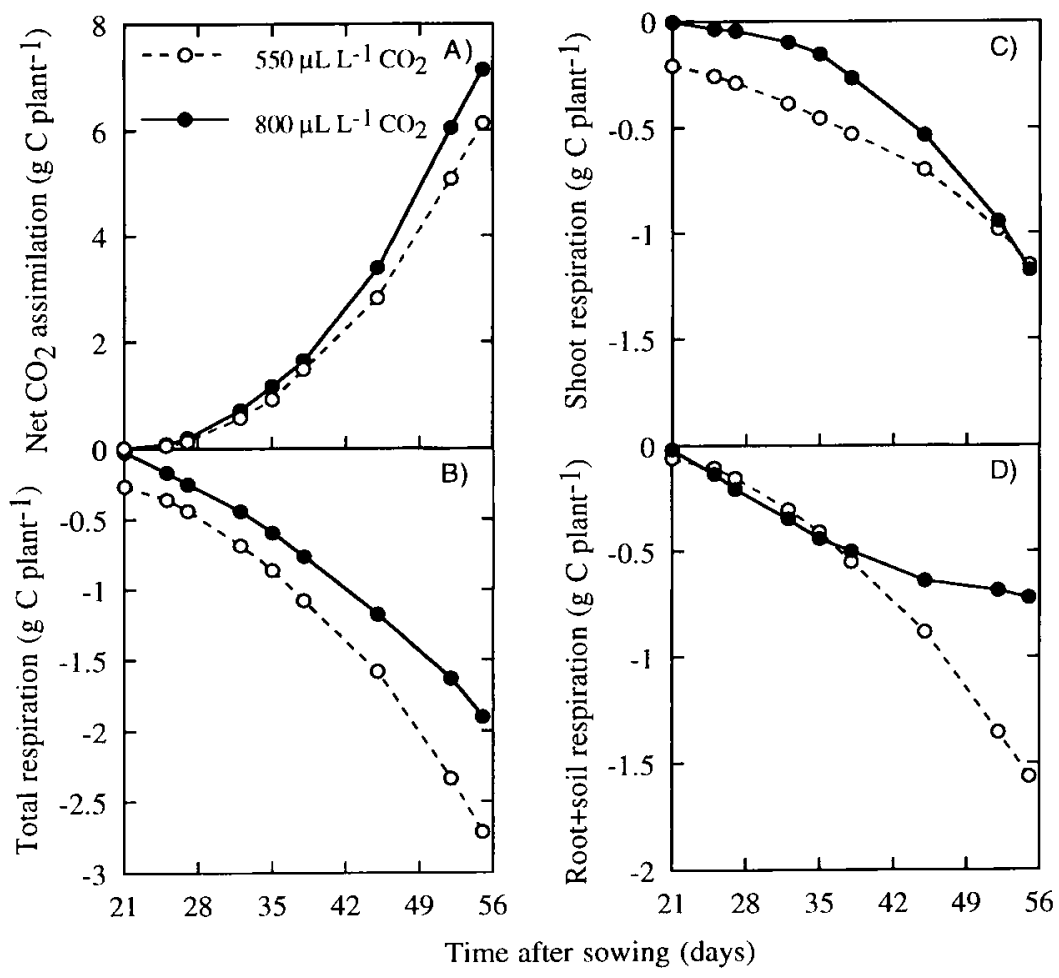

Figure 1. Time course of cumulated respiration and net $\mathrm{CO}_{2}$ assimilation of Juglans regia L. seedlings grown for 55 days under controlled conditions $\left(22^{\circ} \mathrm{C}\right.$, $12 \mathrm{~h}$ ) with 550 or $800 \mu \mathrm{L} \mathrm{L}^{-1} \mathrm{CO}_{2}$ in the atmosphere. Average from 50 to 200 plants. (A) Net $\mathrm{CO}_{2}$ assimilation; (B) total respiration; $(\mathrm{C})^{2}$ shoot respiration; (D) root + soil respiration. 
lation between both $\mathrm{CO}_{2}$ treatments appeared after day 27 and were obvious at day 45 , ending with a notable stimulation by $14 \%$ on day 55 at 800 compared with $550 \mu \mathrm{L} \mathrm{L}^{-1} \mathrm{CO}_{2}$ (figure $1 A$ ).

Comparison of dark shoot respiration revealed marked differences at the occurrence of measurable net $\mathrm{CO}_{2}$ assimilation (figure $1 \mathrm{C}$ ). At day 21 , it was negligible under 800 but already noticeable under $550 \mu \mathrm{L} \mathrm{L}^{-1} \mathrm{CO}_{2}$. Then, the shoot respiration was strongly stimulated under elevated $\mathrm{CO}_{2}$, ending in a cancellation of initial differences on day 55 (figure $1 C$ ).

Subterranean respiration increased gradually with growth, and no differences were observed between the two $\mathrm{CO}_{2}$ treatments until day 37 (figure $1 D$ ). Then, subterranean respiration continued to increase under $550 \mu \mathrm{L} \mathrm{L}^{-1} \mathrm{CO}_{2}$, whereas it was markedly depressed by $46 \%$ on day 55 under $800 \mu \mathrm{L} \mathrm{L}^{-1} \mathrm{CO}_{2}$ (figure $1 D$ ). As a result, after the first 2 months, both increased $C$ assimilation and depressed total respiration (figure $1 A, B$ ) ended in a gain in $\mathrm{C}$ for seedling growth of about $54 \%$ under $800 \mu \mathrm{L} \mathrm{L}^{-1} \mathrm{CO}_{2}$ compared to $550 \mu \mathrm{L} \mathrm{L}^{-1} \mathrm{CO}_{2}$.

\section{2. $\mathrm{C}$ and $\mathrm{N}$ changes in the seedling-seed system}

The $\mathrm{C}$ and $\mathrm{N}$ content of seeds decreased gradually until day 40 , and then stabilized after this date. A loss of about $78 \%$ of $\mathrm{C}$ and of about $86 \%$ of $\mathrm{N}$ was recorded on day 55 (figure 2). These changes were similar under both $\mathrm{CO}_{2}$ treatments. The time course of $\mathrm{C}$ or $\mathrm{N}$ content was similar in the seeds under both $\mathrm{CO}_{2}$ treatments suggesting no effect of $\mathrm{CO}_{2}$ on these parameters.

The $\mathrm{C}$ content in the whole seedlings increased exponentially and similarly from day 4 to day 39 under the two $\mathrm{CO}_{2}$ treatments (figure 2). After day 39 , corresponding to the end of $\mathrm{C}$ and $\mathrm{N}$ loss by the seed, and 18 days after beginning of the photosynthetic activity, $\mathrm{C}$ accumulation was favoured under 800 compared to $550 \mu \mathrm{L} \mathrm{L}^{-1} \mathrm{CO}_{2}$, ending in a doubled $\mathrm{C}$ accumulation on day 55 (figure 2 ). This increase was observed in the taproot $(+63 \%)$, roots $(+64 \%)$, stem $(+18 \%)$ and leaves $(+39 \%)$ (figure 3 ). Growth enhancement was larger under $800 \mu \mathrm{L} \mathrm{L}^{-1}$, in roots than shoot, resulting in a higher root:shoot ratio $(\mathrm{R}: \mathrm{S}=0.62)$ relative to $550 \mu \mathrm{L} \mathrm{L}^{-1} \mathrm{CO}_{2}(\mathrm{R}: \mathrm{S}=0.40)$.

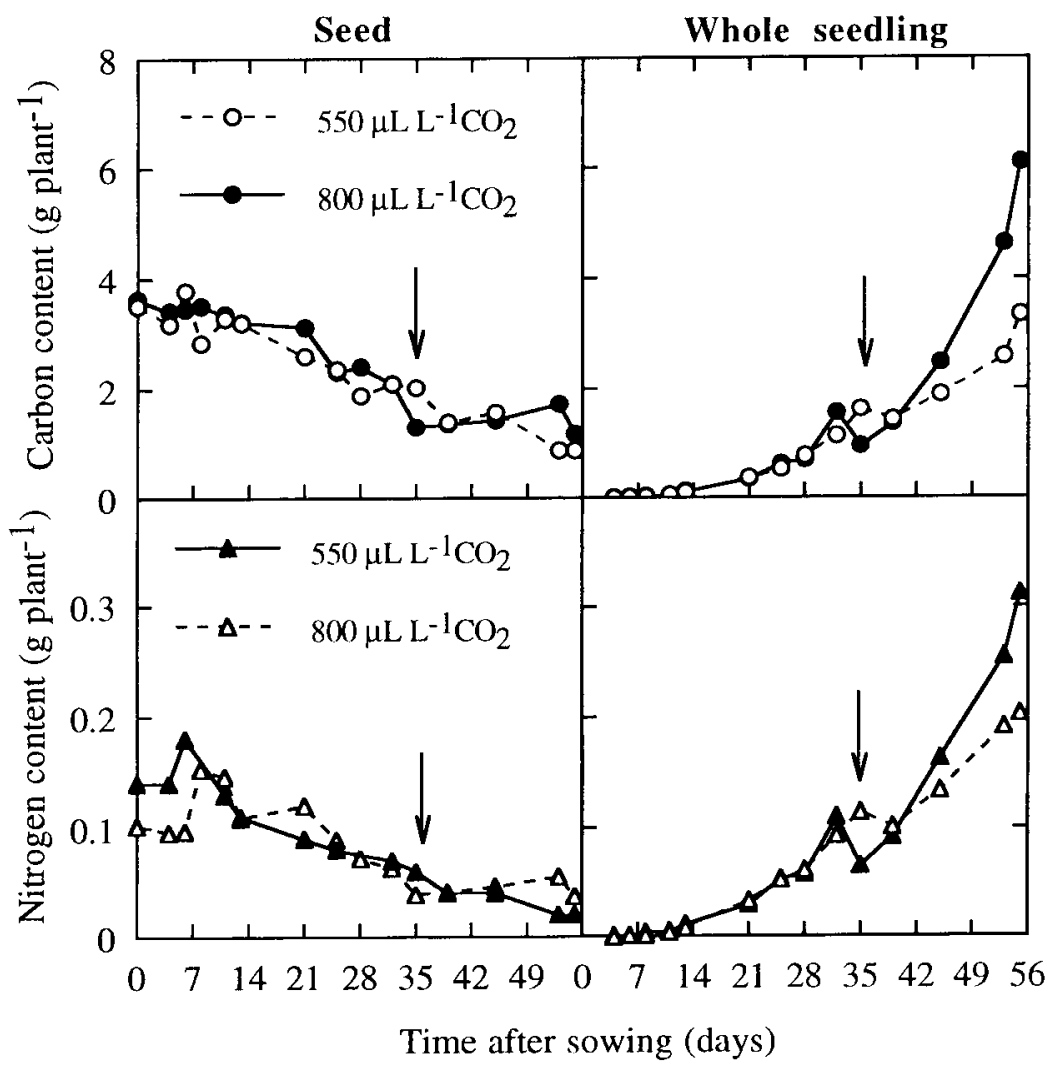

Figure 2. Time course of carbon and nitrogen contents of the walnut seedling-seed systems (Juglans regia L.) grown for 55 days under controlled conditions $\left(22^{\circ} \mathrm{C}, 12 \mathrm{~h}\right)$ with an atmospheric concentration of 550 or $800 \mu \mathrm{L}$ $\mathrm{L}^{-1} \mathrm{CO}_{2}$. The arrows show the date of the complete depletion of carbon and nitrogen reserves of seeds. Each value is the mean of three replicates of a sample originating from five to ten seedlings or seeds. 


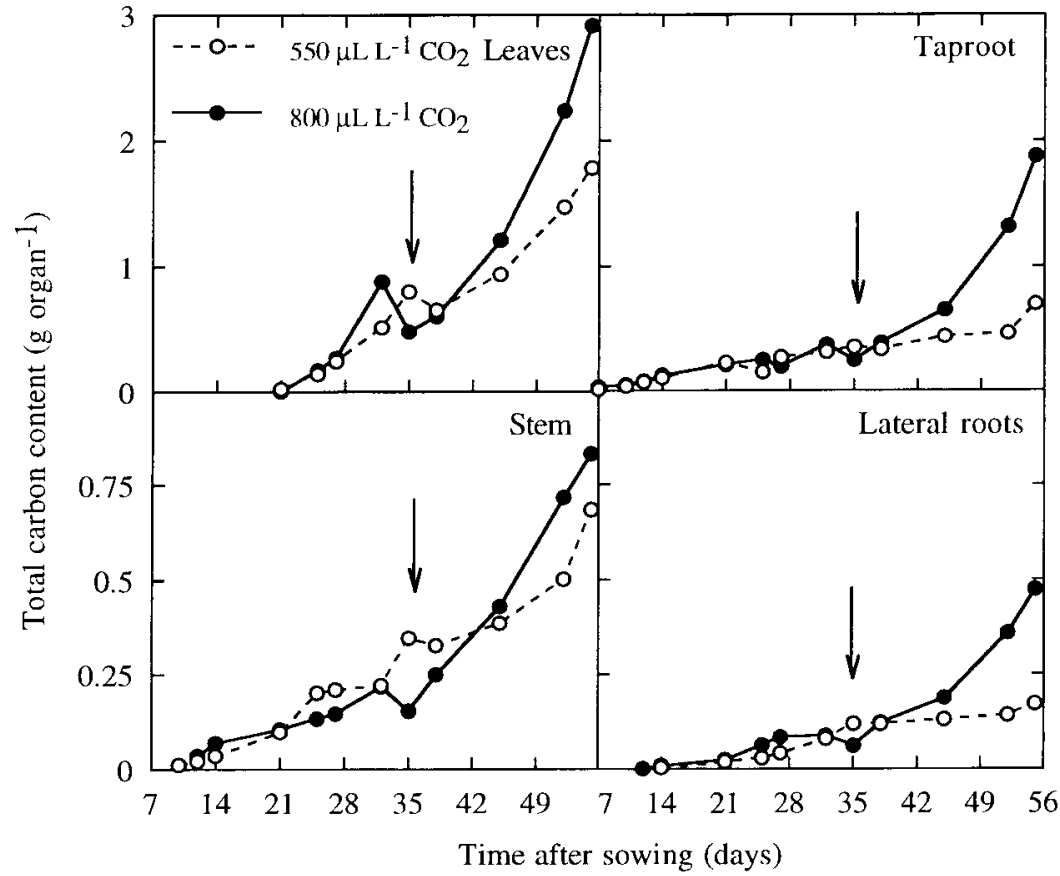

Figure 3. Accumulation of carbon in the various organs of Juglans regia L. seedlings grown for 55 days under controlled conditions $\left(22^{\circ} \mathrm{C}, 12 \mathrm{~h}\right)$ with an atmospheric concentration of 550 or $800 \mu \mathrm{L} \mathrm{L}^{-1} \mathrm{CO}_{2}$. The arrows shows the date of the complete depletion of carbon and nitrogen reserves of seeds. Each value is the mean of three replicates of a sample originating from five to ten seedlings.
The $\mathrm{N}$ content in the whole seedlings increased exponentially and similarly under the two $\mathrm{CO}_{2}$ treatments from day 4 to day 39 (figure 2). After the end of loss of $\mathrm{C}$ and $\mathrm{N}$ by the seed, and 18 days after the beginning of the photosynthetic activity, $\mathrm{N}$ accumulation was more favoured under 800 than under $550 \mu \mathrm{L} \mathrm{L}^{-1} \mathrm{CO}_{2}$, resulting in a $\mathrm{N}$ accumulation increased by about $35 \%$ on day 55 . Differences in the $\mathrm{N}$ content of the subterranean system occurred only after day 38 (figure 4 ). There was more $\mathrm{N}$ accumulated in the taproot and lateral roots under 800 than under $550 \mu \mathrm{L} \mathrm{L}^{-1} \mathrm{CO}_{2}$. As a result, $\mathrm{N}$ in the taproot and lateral roots was increased by +49 and $+54 \%$, respectively, on day 55 (figure 4). Differences in the $\mathrm{N}$ content of the aerial system were less pronounced than in the subterranean one for both $\mathrm{CO}_{2}$ treatments (figure 4). $\mathrm{N}$ content of the stem was notably depressed at $800 \mu \mathrm{L} \mathrm{L}^{-1} \mathrm{CO}_{2}$ from day 20 to day 46 (figure 4). After this period, the stem $\mathrm{N}$ content reached values near that observed at $550 \mu \mathrm{L} \mathrm{L}^{-1} \mathrm{CO}_{2}$. The $\mathrm{N}$ content of leaves varied similarly until day 38 for both $\mathrm{CO}_{2}$ conditions, then, increased faster at $800 \mu \mathrm{L} \mathrm{L}^{-1} \mathrm{CO}_{2}$, resulting in a final value of $+31 \%$ in excess with respect to $550 \mu \mathrm{L} \mathrm{L}^{-1} \mathrm{CO}_{2}$ on day 55 (figure 4).

\section{3. $\mathrm{C}: \mathrm{N}$ ratio variations}

$\mathrm{C}: \mathrm{N}$ ratios were similar in the two treatments until day 38 but diverged thereafter, and were higher for taproot
$(+27 \%)$, lateral roots $(+20 \%)$, the stem $(+28 \%)$ and leaves $(+12 \%)$ under $800 \mu \mathrm{L} \mathrm{L}^{-1} \mathrm{CO}_{2}$ compared with $550 \mu \mathrm{L} \mathrm{L} \mathrm{L}^{-1} \mathrm{CO}_{2}$ (figure 5). $\mathrm{C}: \mathrm{N}$ ratio in the shoot increased before that in roots.

\subsection{Assimilation and allocation of $\mathbf{N}$ in the whole seedling}

Assimilated $\mathrm{N}$ appeared first in the taproot after day 14. Differences between the two $\mathrm{CO}_{2}$ treatments appeared after day 35 , corresponding to the end of the $\mathrm{N}$ supply by the seed (figure 6). After this date, the percentage of $\mathrm{N}$ assimilated from the nutrient solution $(\mathrm{Np})$ by the taproot increased strongly, particularly under $800 \mu \mathrm{L} \mathrm{L}^{-1} \mathrm{CO}_{2}$. As a result on day 55, the taproot contained only recently assimilated $\mathrm{N}$ under $800 \mu \mathrm{L} \mathrm{L}^{-1} \mathrm{CO}_{2}$, whereas $20 \%$ of $\mathrm{N}$ in the taproot was derived from seed reserves under $550 \mu \mathrm{L} \mathrm{L}^{-1} \mathrm{CO}_{2}$. In lateral roots, $\mathrm{Np}$ increased strongly after day 21 and similarly under the two $\mathrm{CO}_{2}$ treatments until day 35. After this date, Np stabilized at about $60 \%$ under 550 and $50 \%$ under $800 \mu \mathrm{L}$ $\mathrm{L}^{-1} \mathrm{CO}_{2}$.

$\mathrm{Np}$ increased strongly in the stem after day 14 to stabilize at about $70 \%$ on day 55 and seemed unaltered by $\mathrm{CO}_{2}$ (figure 6). In contrast, from day 24 to day 55 , the $\mathrm{Np}$ of leaves was always slightly higher under 800 than with $550 \mu \mathrm{L} \mathrm{L}^{-1} \mathrm{CO}_{2}$. Note that this percentage decreased after 

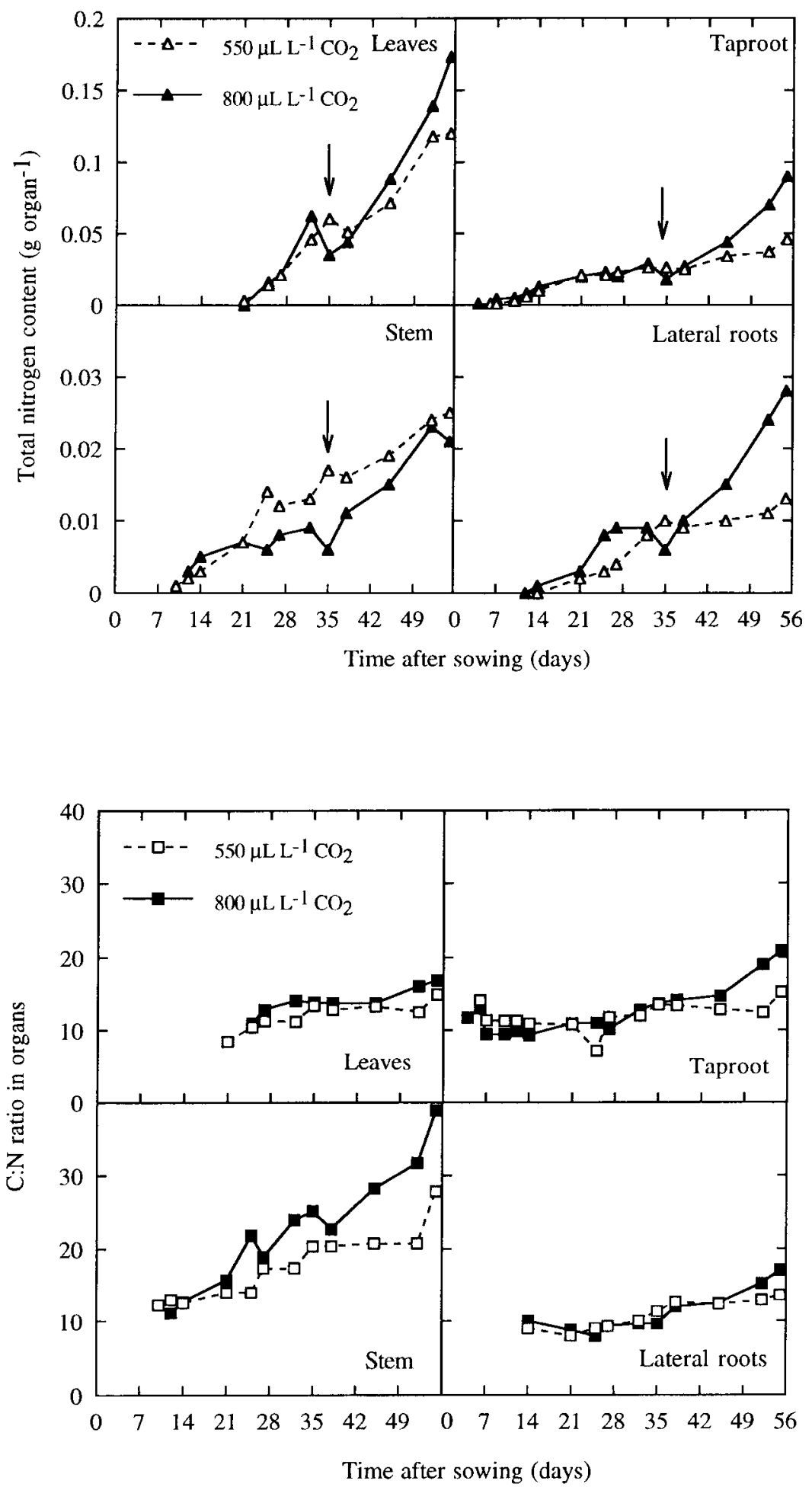

Figure 4. Accumulation of nitrogen (N) in the various organs of Juglans regia $\mathrm{L}$. seedlings grown for 55 days under controlled conditions $\left(22^{\circ} \mathrm{C}\right.$, $12 \mathrm{~h}$ ) with an atmospheric concentration of 550 or $800 \mu \mathrm{L} \mathrm{L}^{-1} \mathrm{CO}_{2}$. The arrows show the date of the complete depletion of carbon and nitrogen reserves of seeds. Each value is the mean of three replicates of a sample originating from five to ten seedlings.

Figure 5. Variation of carbon:nitrogen $(\mathrm{C}: \mathrm{N})$ ratio of the various organs of Juglans regia L. seedlings grown for 55 days under controlled conditions $\left(22^{\circ} \mathrm{C}, 12 \mathrm{~h}\right)$ with an atmospheric concentration of 550 or $800 \mu \mathrm{L} \mathrm{L}^{-1} \mathrm{CO}_{2}$. 


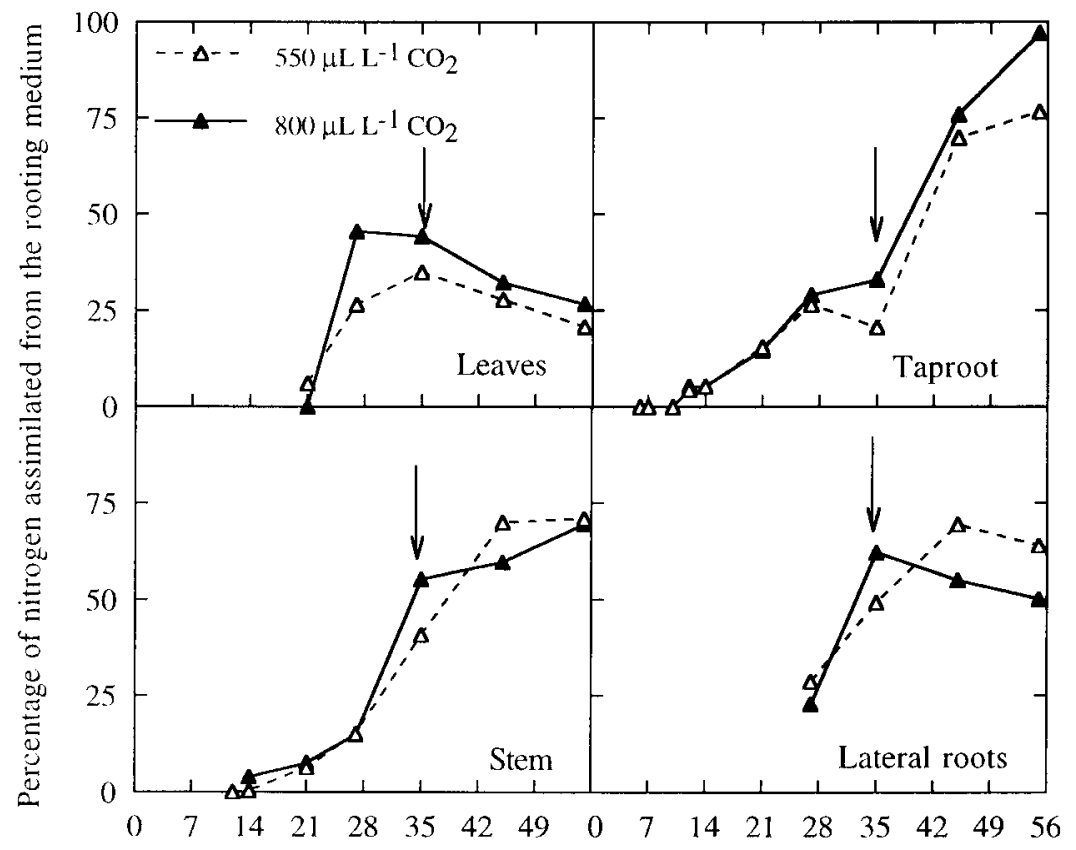

Time after sowing (days)
Figure 6. Time course of the percentage of nitrogen assimilated from the rooting medium $(\mathrm{Np})$ in the various organs of Juglans regia L. seedlings grown for 55 days under controlled conditions $\left(22^{\circ} \mathrm{C}\right.$, $12 \mathrm{~h}$ ) with an atmospheric concentration of 550 or $800 \mu \mathrm{L} \mathrm{L}^{-1} \mathrm{CO}_{2}$. The arrows show the date of the complete depletion of carbon and nitrogen reserves of seeds. Each value is obtained from two replicates of a sample originating from five to ten plants. day 38 and remained at a low level (about $25 \%$ ) compared to the other organs (70-100\%).

Newly assimilated $\mathrm{N}$ on a content basis (Nn) accumulated strongly in the taproot in response to $\mathrm{CO}_{2}$ (figure 7). In contrast, $\mathrm{N}$ content originating from reserves $(\mathrm{Na})$ was not altered. $\mathrm{N}$ originating from both sources increased strongly in lateral roots.

Variations of the $\mathrm{N}$ content of both origins were also notably altered in the shoot in response to $\mathrm{CO}_{2}$. Accumulation of $\mathrm{Nn}$ decreased in the stem without notable alteration of $\mathrm{Na}$ at the end of experiment in the two treatments. Increased total $\mathrm{N}$ content in leaves observed above under $800 \mu \mathrm{L} \mathrm{L}^{-1} \quad \mathrm{CO}_{2}$ was due to increased accumulation of $\mathrm{N}$ of both origins. It was noted that the leaves contained the most important part of $\mathrm{Na}$.

\section{DISCUSSION}

Our results indicate a marked sensitivity of walnut seedlings to $\mathrm{CO}_{2}$ concentration, particularly noticeable at two specific stages during the course toward autotrophy: at the beginning of their ability to photosynthesize (about day 21) and at the time of complete depletion of seed reserves (about day 38). This sensitivity was observed initially on respiration and $\mathrm{C}$ assimilation, whereas alter- ations of $\mathrm{C}$ and $\mathrm{N}$ accumulation in seedlings began to be noticeable only after complete depletion of seed reserves.

\subsection{Effect of $\left[\mathrm{CO}_{2}\right]$ on gas exchanges}

The first noticeable alterations induced by elevated $\mathrm{CO}_{2}$ were encountered in shoot respiration and $\mathrm{C}$ assimilation. This observation differs from that made using young oak seedlings that display a low sensitivity to elevated $\mathrm{CO}_{2}$ concentrations, probably due to the trophic preponderance of the seed for this species during the course toward autotrophy [32].

The observed depressed shoot respiration (figure IC) has been reported before for several woody plants such as oak [40] or chestnut [30]. Reasons for this alteration of metabolism and changes of tissue $\mathrm{N}$ concentrations observed before the complete acquisition of photosynthetic ability by seedlings, remain largely unknown but could be related to a direct effect of $\mathrm{CO}_{2}$ on enzymes of the respiratory pathways $[5,4,16,20]$. Moreover, Curtis [12] suggested that the accumulation of non-structural carbohydrates could account for the decreased dark respiration of leaves of tree species grown under elevated $\mathrm{CO}_{2}$. In the case of heterotrophic walnut seedlings, sensitivity of dark aerial respiration to elevated $\left[\mathrm{CO}_{2}\right]$ was not sus- 


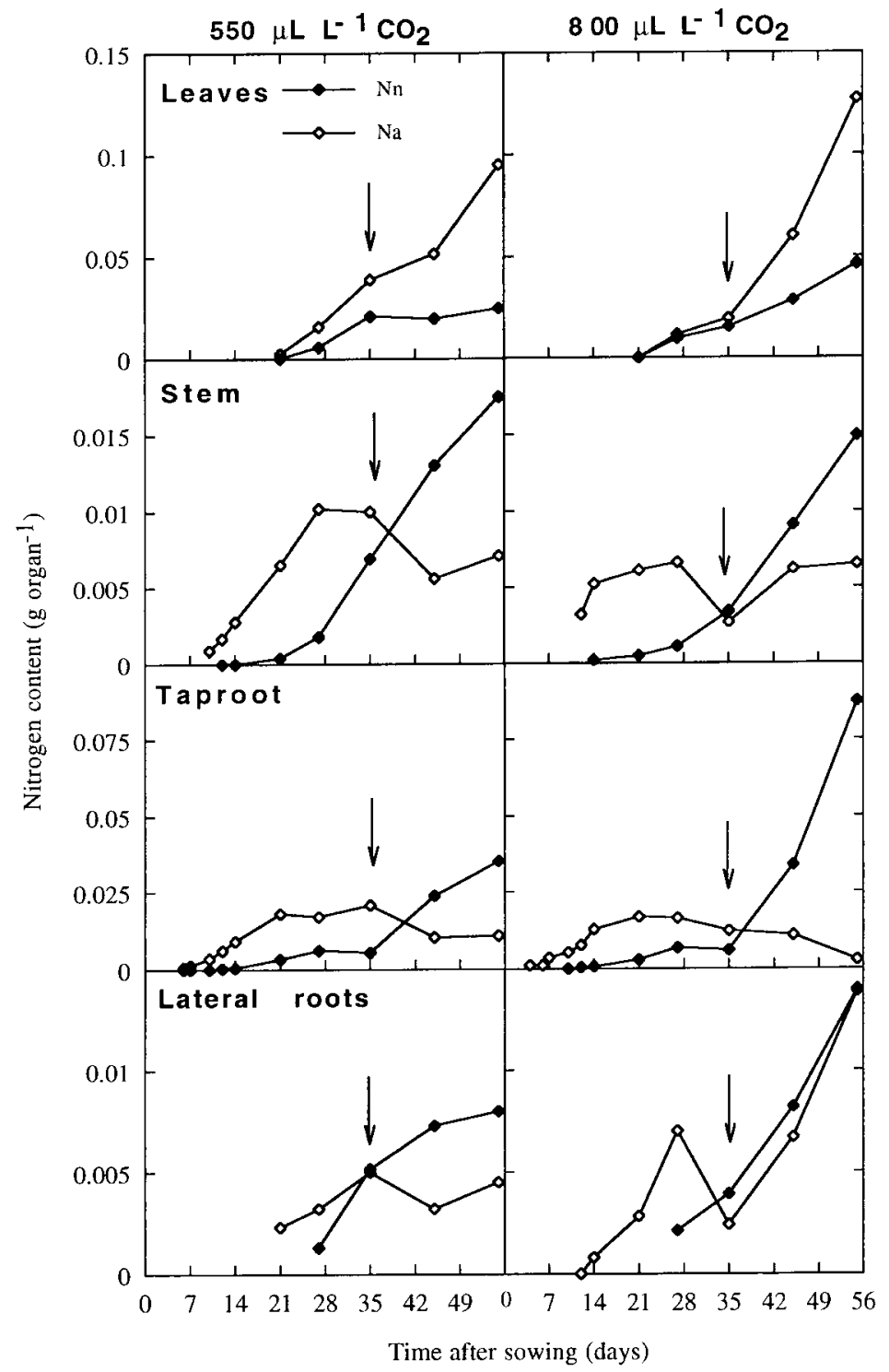

Figure 7. Time course of the nitrogen pool coming from seed reserves ( $\mathrm{Na}$ ) and of assimilation $(\mathrm{Nn})$ in the various organs of Juglans regia $\mathrm{L}$. seedlings grown for 55 days under controlled conditions $\left(22^{\circ} \mathrm{C}, 12 \mathrm{~h}\right)$ with an atmospheric concentration of 550 or $800 \mu \mathrm{L} \mathrm{L}^{-1} \mathrm{CO}_{2}$. The arrows show the date of the complete depletion of carbon and nitrogen reserves of seeds. Each value is obtained from two replicates of a sample originating from five to ten plants. tained after complete depletion of seed reserves (day 39), the time when net $\mathrm{C}$ assimilation was markedly increased by $\mathrm{CO}_{2}$. In fact, aerial respiration was then strongly increased concomitantly with an increased import of $\mathrm{N}$ recently assimilated by leaves and the beginning of an export of recently assimilated $C$ toward roots [27]. These observations suggest that changes in carbohydrate metabolism may occur in the response of aerial respiration of walnut to $\mathrm{CO}_{2}$, in agreement with Curtis [12].

The subterranean respiration of walnut seedlings remained insensitive to the increase of $\left[\mathrm{CO}_{2}\right]$ even after 24 days of photosynthetic activity (figure $1 D$ ). It then decreased markedly under $800 \mu \mathrm{L} \mathrm{L}^{-1} \mathrm{CO}_{2}$, suggesting in this case an indirect effect of elevated $\left[\mathrm{CO}_{2}\right]$ on this component. Many authors report such $\mathrm{CO}_{2}$ effects on trees [6, 30, 37]. As for the alteration of aerial respiration of plants, the mechanisms are largely unknown, but changes in growth: maintenance respiration balance are generally hypothesised [7, 41]. Many causes could be involved in the case of walnut seedlings:

- The dilution of $\mathrm{N}$ recorded in tissues under elevated $\left[\mathrm{CO}_{2}\right]$ could lead to decreased respiration needs.

- The excess of $\mathrm{C}$ assimilated under elevated $\left[\mathrm{CO}_{2}\right]$ would be allocated to the taproot mainly for storage rather 
than for growth, inducing an alteration of the maintenance: growth respiration balance. In fact, the taproot is the main storage organ very early under $550 \mu \mathrm{L} \mathrm{L}^{-1}(40$ $\%$ of total stored starch in the plant; unpublished data) and root respiration begins to be depressed as soon as the roots start to be supplied by $\mathrm{C}$ imported from the leaves ([26] figure l).

- Modifications of the energy cost for ion uptake and nutrient acquisition are also reported in this response of roots to elevated $\mathrm{CO}_{2}$ [14].

\subsection{Effect of $\left[\mathrm{CO}_{2}\right]$ on assimilation and partitioning of $\mathrm{C}$ and $\mathrm{N}$}

$\mathrm{C}$ and $\mathrm{N}$ accumulated more in roots than in shoots in response to elevated $\mathrm{CO}_{2}$, causing an increased root:shoot ratio in walnut seedlings. Increased accumulation of $\mathrm{C}$ in roots was also reported in many studies at elevated $\mathrm{CO}_{2}$ [9] but much less information is available in the literature concerning $\mathrm{N}$ accumulation in roots. As previously described for other species $[9,37]$, an increase in root:shoot ratio was observed in heterotrophic seedlings, suggesting that elevated $\left[\mathrm{CO}_{2}\right]$ induced extra root storage preferentially to shoot storage. Many reports on trees show that elevated $\left[\mathrm{CO}_{2}\right]$ leads to decreased plant $\mathrm{N}$ concentration despite a high $\mathrm{N}$ content of the growth media $[31,36]$. Our results show that whole plant $\mathrm{N}$ pools were increased under the highest $\mathrm{CO}_{2}$ for walnut seedlings but were not high enough to compensate for the increase of $\mathrm{C}$ incorporation. Consequently, $\mathrm{C}: \mathrm{N}$ increased more in the roots, as soon as they imported photosynthates from leaves [26], than in the leaves, probably due to the intensive leaf metabolism at this time.

Despite dilution of $\mathrm{N}$ in walnut seedlings under $\mathrm{CO}_{2}$ enrichment, both an increased assimilation of $\mathrm{N}$ originating from the nutrient solution by taproot and a modified relative distribution of $\mathrm{N}$ were observed. These changes induced by elevated $\left[\mathrm{CO}_{2}\right]$ could be linked both to increased root biomass and to an alteration of root function. This latter point needs further confirmation but differs from results reported for older trees such as oak, where the allocation of ${ }^{15} \mathrm{~N}$ originated from a fertilised soil was not altered by $\mathrm{CO}_{2}$ [36]. In trees, the role of buffer played by the mobilisation of $\mathrm{N}$ reserves in case of temporary depletion can be significant [34]. In very young walnut seedlings such a trophic strategy seems unlikely due to the very intensive growth of the whole plant and to the low level of $\mathrm{N}$ seed reserves at this developmental stage [26, 27]. In this case, the observed increase of ${ }^{15} \mathrm{~N}$ allocation could be an alternative to the effects of the elevated $\mathrm{CO}_{2}$.
In very young walnut seedlings grown under the highest $\mathrm{CO}_{2}$ treatment, increased use of $\mathrm{N}$ coming from both origins was observed in the leaves and lateral roots, suggesting, at this developmental stage, both optimisation of $\mathrm{N}$ assimilation and distribution of stored $\mathrm{N}$ pools in metabolically active organs $[25,26]$. Surprisingly, compared to other organs, high $\mathrm{Na}$ was noted in leaves a long time after seed reserve depletion (figure 7), indicating a late and high use of ancient $\mathrm{N}$ for current metabolism. The permanent and high turnover of proteins in leaves [13] could be responsible for this phenomenon. The fact that the ancient $\mathrm{N}$ content of leaves was increased under 800 compared to $550 \mu \mathrm{L} \mathrm{L}^{-1} \mathrm{CO}_{2}$ could be due to the mobilization and import of old $\mathrm{N}$ reserves from neighbouring organs such as the stem, for example.

In conclusion, our data under 800 compared to $550 \mu \mathrm{L}$ $\mathrm{L}^{-1} \mathrm{CO}_{2}$ confirm that, during the heterotrophy-autotrophy transition, a strong $\mathrm{C}$ supply limitation exists due both to seed and photosynthetic leaves of walnut seedlings and suggest that the root was more affected by the $\mathrm{C}$ supply limitation than shoot growth, in accordance with Escobar-Gutierrez et al. [17]. On the other hand, assimilation and use of $\mathrm{C}$ and $\mathrm{N}$ by very young trees such as walnut seedlings are interrelated and changes in availability or acquisition of one at autotrophy often lead to changes in availability and acquisition of the other as reported by Bassirirad et al. [2] on loblolly and ponderosa pine. Due to the demand for photosynthates, $\mathrm{N}$ assimilation is closely related to the $\mathrm{C}$ metabolism and it was shown, mainly on herbaceous plants, that a surplus of $\mathrm{N}$ can divert photosynthates away from the formation of storage or transport carbohydrates such as starch or sucrose to amino acid or protein synthesis by modifying the activity of some enzymes connecting carbohydrate and amino acid metabolisms [10, 19, 38]. Analysis of changes in amino acid pools and enzyme activities involved in the interaction of carbohydrate and $\mathrm{N}$ metabolism of walnut seedlings could be a useful tool for understanding by which mechanisms the carbon assimilated in excess by leaves under the highest $\mathrm{CO}_{2}$ treatment resulted in 1) an improved efficiency in $\mathrm{N}$ assimilation, 2) an increased use of $\mathrm{N}$ originating from both origins and 3 ) a strongly depressed root respiration. However, our results were obtained under conditions in which $\mathrm{N}$ supply was non-limiting. Whether photosynthesis and growth stimulation of walnut seedlings by $\mathrm{CO}_{2}$ would also be maintained under limited $\mathrm{N}$ supply conditions remains an open question.

Acknowledgements: We would like to thank the research team of the Service Central d'Analyses (CNRS, BP 22, 69390 Vernaison, France) and particularly H. Casabianca for fruitful collaboration concerning the ${ }^{15} \mathrm{~N}$ analyses. Particular gratitude is due to Erwin Dreyer, 
Josette Masle, Graham Farquahr and Professor Pierre Gadal for stimulating discussions during manuscript preparation.

\section{REFERENCES}

[1] Ballaré C.L., Scopel A.L., Sanchez R., Plant photomorphogenesis in canopies, crop growth, and yield. In: Seedling morphogenetical and physiological adaptation to abiotic stress, Am. Soc. Hortic. Sci. (HortScience) 30 (1995) 1172-1181.

[2] Bassirirad H., Griffin K.L., Strain B.R., Reynolds J.F., Effects of $\mathrm{CO}_{2}$ enrichment on growth and root ${ }^{15} \mathrm{NH}_{4}{ }^{+}$uptake rate of loblolly pine and ponderosa pine seedlings, Tree Physiology 16 (1996) 957-962.

[3] Buchmann N., Kao W.Y., Ehleringer J.R., Carbon dioxide concentrations within forest canopies - variation with time, stand structure, and vegetation type, Global Change Biol. 2 (1996) $421-432$.

[4] Buchmann N., Guehl J.M., Barigah T.S., Ehleringer J.R., Interseasonal comparison of $\mathrm{CO}_{2}$ concentrations, isotopic composition, and carbon dynamics in an amazonian rainforest (French Guiana), Oecologia 110 (1997) 120-131.

[5] Bunce J.A., Short and long-term inhibition of respiratory carbon dioxide efflux by elevated carbon dioxide, Ann. Bot. 65 (1990) 637-642.

[6] Bunce J.A., Stomatal conductance, photosynthesis and respiration of temperate deciduous tree seedlings grown outdoors and at an elevated concentration of carbon dioxide, Plant Cell Environ. 15 (1992) 541-549.

[7] Bunce J.A., The effect of carbon dioxide concentration on respiration of growing and mature soybean leaves, Plant Cell Environ. 18 (1995) 575-581.

[8] Canham A.E., McCavish W.J., Some effects of $\mathrm{CO}_{2}$, daylength and nutrition on the growth of young forest tree plants. I. In the seedling stage, Forestry 54 (1981) 169-82.

[9] Ceulemans R., Mousseau M., Tansley review $\mathrm{n}^{\circ} 71$. Effects of elevated atmospheric $\mathrm{CO}_{2}$ on woody plants, New Phytol. 127 (1994) 425-446.

[10] Champigny M.L., Foyer C., Nitrate activation of cytosolic protein kinases diverts photosynthetic carbon from sucrose to amino acid biosynthesis. Basis for a new concept, Plant Physiol. 100 (1992) 7-12.

[11] Cliquet J.B., Deléens E., Bousser A., Martin M., Lescure J.C., Prioul J.L., Mariotti A., Morot-Gaudry J.F., Estimation of carbon and nitrogen allocation during stalk elongation by ${ }^{13} \mathrm{C}$ and ${ }^{15} \mathrm{~N}$ tracing in Zea mays L., Plant Physiol. 92 (1990) 79-87.

[12] Curtis P.S., A meta-analysis of leaf gas exchange and nitrogen in trees grown under elevated carbon dioxide, Plant Cell Environ. 19 (1996) 127 137.

[13] Deléens E., Cliquet J.B., Prioul J.L., Use of ${ }^{13} \mathrm{C}$ and ${ }^{15} \mathrm{~N}$ plant label near natural abundance for monitoring carbon and nitrogen partitioning, Aust. J. Plant Physiol. 21 (1994) 133-46.

[14] Den Hertog J., Stulen I., Lambers H., Assimilation and allocation of carbon in Plantago major as affected by atmos- pheric $\mathrm{CO}_{2}$ levels: a case study, Vegetatio 104/105 (1993) 369-378.

[15] Durr C., Croissance de la plantule de betterave sucrière (Beta vulgaris L.), in: Implantation de la betterave industrielle, Chauny, France, Editions Inra, Paris, Série Les Colloques, 67 (1994) 15-27.

[16] El Cohen A., Réponse du chataignier au $\mathrm{CO}_{2}$ et à deux niveaux de nutrition minérale, thesis, University Paris-Sud Orsay, 1993, $177 \mathrm{p}$

[17] Escobar-Gutierrez A., Daudet F.A., Gaudillère J.P., Maillard P., Frossard J.S., Modelling of allocation and balance of carbon in walnut (Juglans regia L.) seedlings during heterotrophy-autotrophy transition, J. Theor. Biol. 194, 1998, $29-48$.

[18] Frost I., Rydin H., Effects of competition, grazing and cotyledon nutrient supply on growth of Quercus robur seedlings, OIKOS 79 (1997) 53-58.

[19] Galvez S., Gadal P., On the function of the NADPdependent isocitrate dehydrogenase isoenzymes in living organisms, Plant Sci. 105 (1995) 1-14.

[20] Gonzalez-Meler M.A., Ribas-Carbo M., Siedow J.N., Drake B.G., Direct inhibition of plant mitochondrial respiration by elevated $\mathrm{CO}_{2}$, Plant Physiol. 112 (1996) 1349-1355.

[21] Kimball B.A., Carbon dioxide and agricultural yield: an assemblage and analysis of 430 prior observations, Agron. J. 75 (1983) 779-789.

[22] Kimball B.A., $\mathrm{CO}_{2}$ stimulation of growth and yield under environmental constraints, in: Enoch H.Z., Kimball B.A. (Eds.), Carbon Dioxide Enrichment of Greenhouse Crops. II. Physiology, Yield and Economics, CRC Press, Boca Raton, FL, 1986, pp. 53-67.

[23] Kozlowski T.T., Kramer P.J., Pallardy S.G., Light and plant development, in: Kozlowski T.T., Kramer P.J., Pallardy S.G. (Eds.), The Physiological Ecology of Woody Plants, Academic Press Inc., San Diego, CA, 1991, pp. 149-156

[24] Le Blevennec L., Mise au point d'une solution nutritive pour les cultures annuelles et pérennes, Cah. Sci. Techn. Inra 14 (1986) 29-32.

[25] Maillard P., Deléens E., Daudet F.A., Lacointe A., Frossard J.S., Carbon and nitrogen partitioning in walnut seedlings during the acquisition of autotrophy through simultaneous ${ }^{13} \mathrm{CO}_{2}$ and ${ }^{15} \mathrm{NO}_{3}$ long-term labelling, J. Exp. Bot. 45 (1994) 203-210.

[26] Maillard P., Deléens E., Daudet F.A., Lacointe A., Frossard J.S., Carbon economy in walnut seedlings during the acquisition of autotrophy studied by long-term labelling with ${ }^{3} \mathrm{CO}_{2}$, Physiol. Plant. 91 (1994) 359-368.

[27] Maillard P., Deléens E., Daudet F.A., Casabianca H., Falcimagne R., Approche du bilan carboné et azoté chez de jeunes noyers lors de l'acquisition de l'autotrophie à l'aide d'un double marquage à long terme ${ }^{13} \mathrm{C} / 15 \mathrm{~N}$, in: Maillard $\mathrm{P}$., Bonhomme R. (Eds.), Utilisation des isotopes stables pour l'étude du fonctionnement des plantes, Editions Inra, Série Les Colloques, France, ISBN 2-7380-0606-X, 1995, pp. 335-346.

[28] Masle J., Hudson G.S., Badger M.R., Effects of ambient $\mathrm{CO}_{2}$ concentration on growth and nitrogen use in tobacco 
(Nicotiana tabacum) plants transformed with an antisense gene to the small subunit of ribulose-1,5-biphosphate carboxylase/oxygenase, Plant Physiol. 103 (1993) 1075-1088.

[29] Miao S., Acorn mass and seedling growth in Quercus rubra in response to elevated $\mathrm{CO}_{2}$, J. Veg. Sci. 6 (1995) $697-700$.

[30] Mousseau M., Effects of elevated $\mathrm{CO}_{2}$ on growth, photosynthesis and respiration of sweet chesnut (Castanea sativa Mill.), Vegetatio 104 (1993) 413-419.

[31] Overdieck D., Elevated $\mathrm{CO}_{2}$ and the mineral content of herbaceous and woody plants, Vegetation 104/105 (1993) 403-411.

[32] Picon C., Guehl J.M., Aussenac G., Growth dynamics, transpiration and water use efficiency in Quercus robur plants submitted to elevated $\mathrm{CO}_{2}$ and drought, Ann. Sci. For. 53 (1996) 431-446.

[33] Pinto Contreras M., Gaudillère J.P., Efficacité de la croissance du blé lors du passage à l'autotrophie, Plant Physiol. Biochem. 25 (1987) 35-42.

[34] Sauter J.J., Van Cleve B., Seasonal variation of amino acids in the xylem sap of Populus $x$ canadiensis and its relation to protein body mobilization, Trees-Struct Funct 7 (1992) 26-32.

[35] Shishido Y., Kumakura H., Hori Y., Changes in sourcesink interaction and darkening of source and sink leaf in tomato (Lycopersicon esculentum Mill.), J. Jpn. Soc. Hortic. Sci. 62 (1) (1993) 95-102.
[36] Vivin Ph., Effets de l'augmentation atmosphérique en $\mathrm{CO}_{2}$ et de contraintes hydriques sur l'allocation de carbone et d'azote et sur l'ajustement osmotique chez Quercus robur L., PhD thesis, Université Henri Poincaré, Nancy 1, France, 1995, $136 \mathrm{p}$.

[37] Vivin Ph., Gross P., Aussenac G., Guehl J.M., Wholeplant $\mathrm{CO}_{2}$ exchange, carbon partitioning and growth in Quercus robur seedlings exposed to elevated $\mathrm{CO}_{2}$, Plant Physiol. Biochem. 33 (1995) 201-211.

[38] Wallenda T., Schaeffer Ch., Einig W., Wingler A., Hampp R., Seith B., George E., Marschner H., Effect of varied soil nitrogen supply on Norway spruce (Picea abies (L.) Karst). II. Carbon metabolism in needles and mycorrhizal roots, Plant Soil 186 (1996) $361-369$.

[39] Wardlaw I.F., Tansley Review. The control of carbon partitioning in plants, New Phytol. 27 (1990) 341-381.

[40] Wullschleger S.D., Norby R.J., Respiratory cost of leaf growth and maintenance in white oak saplings exposed to atmospheric enrichment, Can. J. For. Res. 22 (1992) 1717-1721.

[41] Wullschleger S.D., Ziska L.H., Bunce J.A., Respiratory responses of higher plants to atmospheric $\mathrm{CO}_{2}$ enrichment, Physiol. Plant. 90 (1994) 221-229.

[42] Ziska L.H., Bunce J.A., The influence of elevated $\mathrm{CO}_{2}$ and temperature on seed germination and emergence from soil, Field Crops Res. 34 (1993) 147-157. 